\title{
GANGGUAN FONOLOGI KELUARAN WICARA PADA PENDERITA AFASIA BROCA DAN AFASIA WERNICKE: SUATU KAJIAN NEUROLINGUISTIK
}

\author{
Nur Arief Sanjaya
}

\begin{abstract}
Abstrak. Penelitian ini bertujuan untuk menemukan bunyi-bunyi konsonan apa saja yang terjadi kesalahan pengucapan pada penderita afasia Broca dan afasia Wernicke yaitu pada kasus kesalahan kata yang diucapkan pada tipologi tunggal. Selanjutnya menyimpulkan persamaan dan perbedaan kesalahan bunyi konsonan pada kedua penderita afasia tersebut. Penelitian ini dilakukan pada semester akhir bulan Januari 2014 - Mei 2014 di Rumah Sakit Dr. Cipto Mangunkusumo. Fokus penelitian ini pada gangguan fonologi pengucapan bunyi konsonan yang diujarkan pasien penderita afasia Broca dan afasia We rnicke, terutama pada penggantian tipologi bunyi-bunyi tunggal. Gangguan fonologi terdiri dari tiga aspek, yaitu penghilangan, penambahan, dan penggantian bunyi konsonan. Objek penelitian yang diteliti adalah tuturan 2 penderita afasia Broca dan 2 penderitan afasia Wernicke yang mengalami kesulitan berbicara disaat pengucapan bunyi konsonan sehingga pasien mengalami gangguan fonologi. Penelitian ini menggunakan metode deskriptif kualitatif dengan mendeskripsi dan menganalisis berdasarkan rangkuman analisis yang diturunkan dari teori fonologi bahasa Indonesia. Instrumen pada penelitian ini adalah peneliti sendiri dibantu dengan tabel analisis data, yaitu TADIR untuk mengetahui jenis afasia apa yang diderita pasien dan hasil Tes Pemeriksaan Kemampuan Wicara untuk mengetahui kesalahan fonologi yang telah diderita pasien. Hasil penelitian ini menunjukan bahwa gangguan fonologi pada penderita afasia Broca sebanyak $151 \mathrm{kata}$, antara lain: penghilangan bunyi konsonan 50 data dengan rata-rata 44,73, penambahan bunyi konsonan 18 data dengan rata-rata 50,44, penggantian bunyi konsonan 83 data dengan rata-rata 29,55. Pada afasia Wernicke sebanyak 208 kata, antara lain: penghilangan bunyi konsonan 69 data dengan rata-rata 36,49, penambahan bunyi konsonan 22 data dengan rata-rata 29,89, penggantian bunyi konsonan 117 data dengan rata-rata 29,40. Persamaan gangguan fonologi dari dari kedua pasien tersebut sebanyak 32 data dan perbedaan dari gangguan fonologi tersebut sebanyak 13 data yang dihasilkan afasia Broca dan sebanyak 24 data yang dihasilkan afasia Wernicke.
\end{abstract}

Kata Kunci: Neurolinguistik, Afasia Broca, Afasia Wernicke, dan Gangguan Fonologi

\section{PENDAHULUAN}

Manusia dilahirkan sebagai makhluk sosial yang selalu berinteraksi dengan manusia lainnya di dalam lingkungan sosial. Dalam kehidupan sehari-hari, alat interaksi sosial yang digunakan dalam aktivitasnya adalah bahasa. Bahasa digunakan untuk mengekspresikan gagasan dan pikiran manusia dalam hal bekerja sama, berkomunikasi, dan mengidentifikasikan diri (Chaer, 1994:32). Hal ini bertujuan agar terjalinnya kebutuhan-kebutuhan yang diperlukan dalam tingkah laku manusia dan hubungannya dengan sesama.Sebagai salah satu wujud tingkah laku manusia, aktivitas berbahasa dalam bentuk ujaran tentu tidak terlepas dari kontrol otak sebagai pusat kendali dari semua kegiatan yang dilakukan oleh manusia. Terdapat proses panjang dan cepat yang dilakukan 
oleh otak dalam proses berbahasa. Hingga bahasa memiliki ciri di antaranya yaitu terdapat bunyi dan makna.

Bahasa memiliki makna apabila lambang-lambang bunyi bahasa yang bermakna berupa satuan-satuan bahasa yang berwujud morfem, kata, frase, klausa, kalimat, dan wacana. Sedangkan bunyi pada bahasa apabila diucapkan oleh alat-alat ucap manusia (Chaer, 1994:42). Namun, tidak semua orang bisa berbahasa dengan baik dan benar. Ada juga seseorang dalam menyampaikan gagasan dan perasaannya melalui bahasa bisa saja tidak tepat. Hal ini diakibatkan beberapa faktor seperti terjadinya kerusakan pada otak dan atau kerusakan pada alat-alat ucap. Kerusakan yang dapat berdampak pada ketidakmampuan seseorang untuk merespon rangsangan dari luar. Sehingga makna dan bunyi yang diutarakan oleh orang tersebut selalu tidak sesuai konteksnya. Terjadinya kerusakan pada otak inilah yang menyebabkan seseorang mengalami gangguan berbahasa.

Gangguan berbahasa secara garis besar dapat dibagi dua. Pertama, gangguan faktor medis; dan kedua akibat faktor lingkungan. Yang dimaksud dengan faktor medis adalah gangguan baik akibat fungsi otak maupun akibat kelainan alat-alat bicara. Sedangkan yang dimaksud dengan faktor lingkungan sosial adalah lingkungan kehidupan yang tidak alamiah manusia, seperti tersisih atau terisolasi dari lingkungan kehidupan masyarakat manusia yang sewajarnya (Chaer, 2003:148). Gangguan berbahasa merupakan salah satu jenis kelainan perilaku komunikasi, di mana penderita mengalami kesulitan atau kehilangan kemampuannya dalam berbahasa akibat kegagalan penderita dalam mencapai tahap-tahap perkembangan bahasanya.Pada dasarnya, kerusakan pada otak yang menjadi penyebab gangguan berbahasa dapat terjadi di kedua hemisfer otak, yaitu hemisfer kiri dan hemisfer kanan.

Hemisfer kanan memiliki peranan mengendalikan semua fonem suprasegmental (aspek-aspek intonasi atau prosodi) dan tona suara, ekspresi muka, dan gerak-gerik badan waktu bertutur dan juga makna perumpamaan dan ungkapan-ungkapan idiomatik (Soejono, 1991: 7). Pemahaman kalimat akan terganggu jika hemisfer kanan mengalami kerusakan, karena hemisfer kanan bertangggung jawab mengendalikan makna- makna tersirat. Selain itu, hemisfer kanan juga berfungsi untuk semua hal- hal yang berkaitan dengan ideasi yang bukan bahasa, seperti kebolehan konstruksi, pengenalan muka dan garis-garis gambar yang rumit, musik dan lagu ruang, dan segala sesuatu yang termasuk ke dalam bawah sadar. Apabila yang terjadi adalah kerusakan pada he misfer kiri, maka gangguan bahasa yang timbul adalah afasia. Afasia merupakan gangguan bahasa perolehan yang disebabkan oleh cidera otak dan ditandai oleh gangguan pemahaman serta gangguan pengutaraan bahasa, lisan, maupun tulisan (Reni, 1993:7).

Afasia juga merupakan kesalahan penderita dalam pengungkapan pikiran, yaitu tidak terjadinya sinkronisasi antara sesuatu yang dipikirkan dengan apa yang diungkapkan. Hal tersebut disebabkan karena hemisfer bagian kiri yang mengatur pusat bahasa telah rusak. Umumnya, penderita afasia mengalami gangguan berbahasa baik secara fonologi, morfologi, sintaksis, semantik dan pragmatik. Penderita afasia dapat mendengar orang lain berbicara tetapi ia mengalami kesulitan untuk memahami mereka. Ia dapat melihat dengan baik huruf, buku atau surat kabar, tetapi tidak dapat mengerti apa yang tertera di situ. Afasia bisa sedemikian parah hingga pasien hampir tidak dapat mengatakan atau memahami sesuatu pun. Atau mungkin afasia sedemikian ringan, sehingga lingkungannya tidak menyangkanya, tetapi pasien itu tahu bahwa ia terkadang mengalami kesulitan kata yang tepat dan tidak lagi menguasai bahasa semudah semula (Reni, 1993:5). Selanjutnya, kerusakan di daerah sensorik, menyebabkan afasia sensorik atau afasia Wernicke, yang menunjukkan ciri-ciri keluaran wicara fasih/fluent, tetapi tidak ada maknanya bagi pendengarnya. 
Daerah sensorik posterior ini merupakan pusat auditoris dan tempatnya di konvolusi pertama lobus temporal disebut area Wernicke. Gangguan bahasa karena kerusakan di daerah ini menyebabkan afasia sensorik yang kemudian juga disebut afasia Wernicke, berdasarkan nama penemunya. Hubungan kerusakan otak dan gangguan berbahasa semakin banyak mendapat perhatian para ahli hingga bidang kajian ini dikenal sebagai afasiologi. Kemudian ilmu lain yang mempelajari hubungan otak dengan bahasa dikenal dengan neurolinguistik. Neurolinguistik merupakan kajian antardisipliner dari dua macam ilmu, yaitu neurologi dan linguistik. Dalam kajian ilmu neurolinguistik banyak mengambil keuntungan dari kerjasama di antara neurologi, linguistik, dan psikolinguistik. Dalam penerapannya, ilmu neurolinguistik bukan hanya mengetahui hakikat hubungan di antara otak dan bahasa tetapi juga melakukan pengobatan terhadap penyakit bertutur yang disebabkan afasia.

Tujuan utama neurolinguistik untuk mengetahui bagaimana bahasa disimpan dan bagaimana bahasa itu diproses di dalam otak dari awal pemerolehan bahasa sampai bahasa itu berkembang dalam kehidupan manusia. Dengan kata lain neurolinguistik ingin mengetahui bagaimana otak diatur pada waktu mengelola aspek-aspek kemampuan dan perlakuan bahasa yang begitu rumit. Penyakit-penyakit afasia dan pengkajiannya telah memberikan ilham kepada neurolinguistik untuk merumuskan bagaimana bahasa disimpan dan diproses dalam otak dan bagaimana bahasa ini berkembang. Penelitian yang berkaitan dengan bidang neurolinguistik umumnya sudah banyak dijumpai dengan objeknya penderita afasia Broca atau afasia Wernicke. Penelitian yang sudah ada tersebut, umumnya hanya membahas mengenai gangguan wicara keluaran dari segi fonologi, gramatikal ataupun semantiknya saja dengan satu jenis penderita afasia.

Namun, sepengetahuan penulis belum ada yang membandingkan keluaran wicara pada penderita afasia Broca dengan afasia Wernicke. Padahal secara nyata kemampuan berbahasa antara penderita afasia Broca dan afasia Wernicke sangatlah berbeda. Pada afasia Broca biasanya ditandai dengan berkurangnya jumlah ujaran, gangguan artikulasi, kelambanan dan kesulitan menghasilkan ujaran. Hampir seluruh ujaran terdiri dari morfem- morfem leksikal seperti nomina dan verba. Sedangkan pada afasia Wernicke, penderita masih dapat menghasilkan ujaran secara lancar, tetapi seringkali sulit diterima secara logis. Ciri khas dari afasia Wernicke ini banyak kata yang tidak cocok maknanya dengan kata-kata lain sebelum dan sesudahnya. Lebih singkatnya, afasia ini merupakan ketidakmampuan dalam memahami lawan bicara.

Dalam keluaran wicaranya tersebut, penderita afasia Broca maupun afasia Wernicke sering melakukan penghilangan, penambahan dan penggantian bunyi-bunyi vokal maupun konsonan pada kata-kata yang diucapkan. Penghilangan, penambahan dan penggantian bunyi tesebut lazim dikenal dengan gangguan fonologi. Umumnya, gangguan fonologi pada penderita afasia memiliki kesalahan tipologi pada kata yang di ucapkan, baik itu tipologi tunggal, tipologi ganda, tipologi tiga dst. Berdasarkan fakta- fakta tersebut, maka penulis bermaksud membuat penelitian terhadap penderita afasia Broca dan afasia Wernicke dengan mengkaji keluaran wicaranya berdasarkan aspek fonologinya. Pemfokusan penelitian ini dengan mencari tahu kesalahan pengucapan bunyi artikulasi konsonannya. Selanjutnya, penulis mencocokkan persamaan dan membandingkan perbedaaan kesalahan pengucapan bunyi artikulasi konsonan terhadap penderita afasia Broca dengan afasia Wernicke supaya didapat gambaran yang jelas mengenai aspek fonologinya.

Dalam penelitian ini teori yang digunakan adalah teori-teori neurolinguistik dan teori-teori linguistik. Teori-teori neurolinguistik yang akan penyusun gunakan berkaitan dengan hakikat otak manusia, fungsi kebahasaan otak, hakikat afasia dan jenis-jenis afasia, 
terutama pada afasia Broca dan afasia Wernicke serta kekhasan keluaran wicara penderitanya. Selanjutnya, teori-teori linguistiknya merupakan teori yang diperlukan sebagai dasar dan acuan analisis gangguan fonologi keluaran wicara penderita afasia Broca dan afasia Wernicke tersebut. Seluruh sistem saraf manusia terdiri dari dua bagian utama, yaitu tulang punggung yang terdiri dari sederetan tulang yang bersambung-sambung (spinal cord) dan otak manusia (Soenjono, 2012:203). Segala ihwal yang dilakukan manusia, baik yang berupa kegiatan fisik maupun mental dikendalikan oleh sistem saraf ini. Secara garis besar, sistem otak yang terdapat pada manusia terdiri dari tiga bagian antara lain: (1) otak besar (serebrum) (2) otak kecil (serebelum), dan (3) batang otak (trunkusserebri). Otak besar terbagi lagi menjadi dua bagian (disebut juga hemisfer) kiri dan kanan.Bagian kiri dan kanan memiliki fungsi yang berbeda antara keduanya. (Soenjono, 2012:3).

Secara lebih terperinci lagi keduanya terdiri dalam bagian-bagian yang disebut lobus yang sama yaitu bagian depan (lobus frontal), samping (lobus temporal), tengah (lobus parietal), belakang (lobusoksipital). Lobus Frontal berpengaruh terhadap perilaku. Lobus yang terletak di bagian dahidepan ini juga merupakan pusat bicara, terutama yang sebelah kiri. Bagian ini yang membuat manusia dapat berbicara dengan lancar, mengungkapkan pikirannya melalu perkataan karena diatur oleh otak frontal (Soenjono, 2012:4). Lobus Te mporal bertanggung jawab soal ingatan. Bagian ini juga berperan sebagai pusat bahasa tetapi bukan untuk bicara sebagaimana yang dilakukan oleh bagian depan, melainkan dalam hal pengertian bahasa (reseptif). Dengan bantuan lobus yang terletak di samping kepala ini orang bisa mengerti apa yang dibicarakan orang lain. Jadi, apa yang diterima melalui pendengaran akan diartikan oleh temporal kiri (Soenjono, 2012:4).

Lobus Parietal bagian ini memungkinkan manusia dapat merasakan sesuatu melalui indera perasa. Lobus yang letaknya di bagian tengah di permukaaan korteks ini akan menerjemahkan apa yang dirasakan. Apabila terjadi kerusakan pada daerah ini menyebabkan hemianestesia, yaitu gangguan perabaan di sisi lain tubuh (Reni, 1993:21). Lobus Oksipital merupakan pusat penglihatan. Di bagian ini manusia mengerti apa yang dilihat karena telah diproses atau diintegrasi. Kalau lobus yang letaknya di belakang ini terganggu, maka akan ada gangguan juga dalam interpretasi hasil penglihatan oleh mata (Achmad, 2007:4). Otak Kecil (Cerebellum) adalah struktur yang melekat pada batang otak melalui peduncles cerebellar yang muncul seperti otak kedua yang lebih kecil. Hal ini dibagi menjadibelahan kanan dan kiri dengan struktur garis tengah disebut sebagai vermis. Otak kecil memiliki lipatan yang mirip dengan korteks serebral, yang disebut folia (Schoenberg, 2011:67).

Otak kecil terletak di arkiserebellum lobules flokulono dulari, yaitu bagian cerebellum yang letaknya paling bawah yang mendapat asupan dari sistem vestibularis dan berfungsi mengurus keseimbangan (Suprapti, 2003:6). Otak kecil berfungsi mengontrol keseimbangan (misalnya untuk berjalan) dan melakukan gerakan yang terkoordinir terutama untuk aktivitas motorik. Seluruh aktivitas motorik manusia dikoordinasi oleh otak kecil. Batang otak merupakan sebutan untuk kesatuan dari tiga struktur yaitu medullaoblongata, pons dan mesencephalon (otak tengah). Pada gerak volunter, batang otakmerupakan jalur yang dilalui impuls rangsang sebelum mencapai serebrum. Impuls rangsang dihantarkan oleh traktus ascendentes (serat-serat saraf yang menghantarkan impuls ke otak) untuk diolah di otak, lalu impuls respons dihantarkan oleh traktus descendentes (serat-serat saraf yang menghantarkan impuls menjauhi otak). Batang otak ini berfungsi menyalurkan informasi ke atau dari otak. 
Otak besar terbagi atas dua hemisfer, kiri dan kanan. Hemisfer kiri bertanggung jawab tentang ihwal kebahasaan karena di hemisfer ini terdapat medan Wernicke dan medan Broca. Medan Wernicke yang berfungsi sebagai pemahaman ujaran dan medan Broca yang berfungsi dalam menghasilkan ujaran. Selain itu, hemisfer kanan juga berperan penting dalam proses berbahasa sebagai pengatur intonasi kalimat. Gangguan bahasa yang terjadi karena adanya cidera otak atau gangguan fungsi otak terutama pada daerah pusat bahasa dinamakan afasia. Afasia umumnya disebabkan karena adanya Gangguan Peredaran Darah Otak (GPDO) yaitu penghentian pengaliran darah ke sebagian otak. Penghentian ini disebabkan oleh emboli, trombosis, atau perdarahan. Namun ada juga disebabkan karena tumor otak, trauma berkepanjangan dan infeksi pada telinga sehingga menyebabkan lobus temporalis rusak.

Gangguan berbahasa yang disebabkan karena adanya kerusakan pada daerah frontal parietal di hemisfer kiri (daerah suprasylvis, baik operculum maupun insula) disebut sebagai afasia Broca. Hal ini karena daerah tersebut berdekatan dengan jalur korteks motor yang berfungsi mengatur alat-alat ujaran. Ciri-ciri dari afasia ini terganggu dalam hal berujar, seperti berkurangnya jumlah ujaran, gangguan artikulasi, kelambanan dan kesulitan menghasilkan ujaran, serta bicara tidak spontan dan ditandai dengan adanya agramatisme. Afasia Wernicke merupakan salah satu jenis gangguan berbahasa yang diakibatkan oleh cidera otak pada hemisferium yang dominan. Daerah ini terletak di kawasan asosiatif antara daerah visual, daerah sensorik, daerah motorik dan daerah pendengaran. Kerusakan di daerah ini menyebabkan bukan saja pengertian dari apa yang didengar (pengertian auditorik) terganggu, tetapi juga pengertian dari apa yang dilihat (pengertian visual) ikut terganggu.

Kalimat-kalimatnya sukar dimengerti karena banyak kata yang tidak cocok maknanya dengan kata-kata lain sebelum dan sesudahnya. Selain itu, penderita juga kehilangan pengertian bahasa lisan dan tulisan. Ciri khas lain dari sindrom afasia Wernicke dalam berbicara, adanya gejala parafrasia yaitu penggantian kata/frasa dalam pembicaraannya. Bahasa dihasilkan oleh alat ucap manusia sehingga menghasilkan bunyi bahasa. Bunyi bahasa dibedakan oleh fonem. Ilmu yang mempelajari tentang bunyi bahasa adalah fonetik dan fonologi. Fonetik sendiri terbagi dalam 3 jenis, yaitu fonetik organis, fonetik akustik dan auditoris. Namun, yang akan dibahas di sini adalah fonetik artikulatoris atau fonetik organis yang berhubungan langsung dengan artikulasi pada manusia. Artikulasi termasuk kajian fonetik artikulatoris karena mengkaji dan mempelajari anatomi dan fisiologi dari organ manusia yang menghasilkan ujaran, pandangan terhadap ujaran sebagai gelombang bunyi yang bisa dianalisis dari segi fisiknya dan pandangan terhadap bagaimana bunyi ujaran itu diterima oleh pendengarnya.

Hal yang menjadi faktor utama penyakit afasia adalah sulitnya bertutur kata dalam proses komunikasi sehingga menyulitkan lawan bicaranya dalam memahami ujaran. Padahal bertutur kata merupakan proses berbahasa yang terdiri dari bunyi-bunyi yang dihasilkan oleh alat ucap manusia. Bunyi-bunyi bahasa yang dimaksud bukanlah bunyi biasa tetapi bunyi yang memiliki makna. Bunyi-bunyi tersebut diselidiki oleh bidang ilmu fonologi dan fonetik. Fonologi meneliti bunyi bahasa berdasarkan fungsinya sedangkan fonetik meneliti bunyi bahasa menurut cara pelafalannya dan menurut sifat-sifat akustiknya. Proses terjadinya bunyi bahasa dimulai dengan pernapasan atau arus udara, kemudian paru-paru dan udara dijadikan sebagai sumber tenaganya. Dalam pembentukan bunyi bahasa tersebut, ada tiga faktor utama yang berperan penting, yaitu sumber tenaga (arus udara), alat ucap yang menimbulkan getaran (titik artikulasi/hambatan), dan rongga pengubah getaran (bergetar/tidaknya pita suara). Dari ketiga proses tersebut, maka bunyibunyi bahasa yang dihasilkan akan dikelompokkan dalam klasifikasi bahasa. 
Konsonan merupakan salah satu klasifikasi bunyi bahasa berdasarkan ada tidaknya hambatan. Bunyi konsonan terjadi karena adanya hambatan pada saat pengucapannya. Bunyi konsonan dapat diklasifikasikan melalui tiga kriteria, yaitu titik artikulasi, cara hambatan, dan ikut bergetar tidaknya pita suara. Konsonan-konsonan tersebut dikelompokkan berdasarkan tiga kriteria bunyi yang dimaksud. Konsonan juga memiliki variasi atau alofon terhadap bunyi konsonan pada saat pengucapan. Alofon ini terdiri dari 20 jenis. Setiap konsonan dapat menempati posisi awal, tengah, dan akhir pada suku kata. Gangguan dalam berbicara adalah salah satu jenis kelainan perilaku komunikasi yang ditandai dengan adanya kesalahan proses produksi bunyi bicara. Gangguan fonologi merupakan gangguan berbahasa seseorang yang diakibatkan adanya kerusakan pada bagian otak, baik sebagian maupun menyeluruh. Hal ini dapat mengakibatkan seseorang tidak dapat berbicara dan berbahasa dengan normal pada umumnya. Efeknya, tidak dapat berkomunikasi dengan baik karena pengucapan bunyi-bunyi bahasa diucapkan tidak jelas. Aspek-aspek gangguan fonologi yang sering dijumpai adalah penghilangan bunyi, penambahan bunyi dan penggantian bunyi.

\section{METODOLOGI PENELITIAN}

Penelitian ini dilakukan untuk menemukan bunyi-bunyi konsonan apa saja yang terjadi kesalahan pengucapan pada penderita afasia Broca dan afasia Wernicke yaitu pada kasus kesalahan kata yang diucapkan pada tipologi tunggal. Selanjutnya menyimpulkan persamaan dan perbedaan kesalahan bunyi konsonan pada kedua penderita afasia tersebut.Penelitian ini menggunakan metode kualitatif dengan pendekatan deskriptif. Metode ini membatasi penelitian deskriptif sebagai penelitian yang menggambarkan keadaan objek penelitian pada saat tertentu berdasarkan fakta- fakta yang tampak atau sebagaimana adanya. Dalam penelitian ini, ujaran penderita afasia dideskripsikan dan dia nalisis berdasarkan rangkuman analisis yang diturunkan dari teori fonologi bahasa Indonesia

Metode penelitian kualitatif dengan pendekatan deskriptif dipilih karena penulis secara langsung mengamati keluaran wicara objeknya yaitu penderita afasia afasia Broca dan afasia Wernicke. Selanjutnya, penulis memperoleh data berupa gangguan fonologi dari keluaran wicara penderita afasia tersebut.Penelitian ini termasuk penelitian lapangan yang menjadikan masyarakat bahasa sebagai objek kemudian dikaitkan dengan gejala-gejala kebahasaan yang muncul. Penelitian ini dilaksanakan di Bagian Neurologi RSCM, Salemba, Jakarta Pusat. Berdasarkan jangkauan waktu, maka penelitian ini tergolong penelitian sinkronis yang terbatas pada waktu tertentu. Penelitian sinkronis ini dilakukan mulai Januari 2014 hingga Mei 2014.

Penelitian ini menganalisis keluaran wicara pada penderita afasia Broca \& afasia Wernicke dari segi fonologinya, yaitu difokuskan pada kesalahan pengucapan pada bunyibunyi konsonannya saja. Bunyi-bunyi konsonan yang diambil hanyalah pada kasus tipologi tunggal dari penghilangan, penambahan dan penggantian bunyi.Objek dalam penelitian ini adalah tuturan 2 penderita afasia Broca dan 2 penderita afasia Wernicke yang terdiri dari laki- laki dan perempuan yang datang ke bagian neurologi RSCM, Jakarta. Kriteria penderita afasia ini berusia antara 40 sampai 65 tahun. Kondisi penderita afasianya juga tidak terlalu parah, melainkan masih bisa berucap dengan jelas fonemfonemnya.Instrumen penelitian ini berupa dua pertanyaan pengarah yang bisa memancing wicara responden. Selain itu digunakan juga tes TADIR dan tabel pemeriksaan kemampuan wicara. Tes TADIR berfungsi untuk mengetahui tingkat keparahan afasia dan jenis afasia apa yang diderita penderita afasia. Tes Pemeriksaan Kemampuan Wicara untuk 
mengetahui gangguan berbahasa pada penderita afasia Broca dan afasia Wernicke, terutama pada kesalahan gangguan fonologinya.

\section{HASIL DAN PEMBAHASAN}

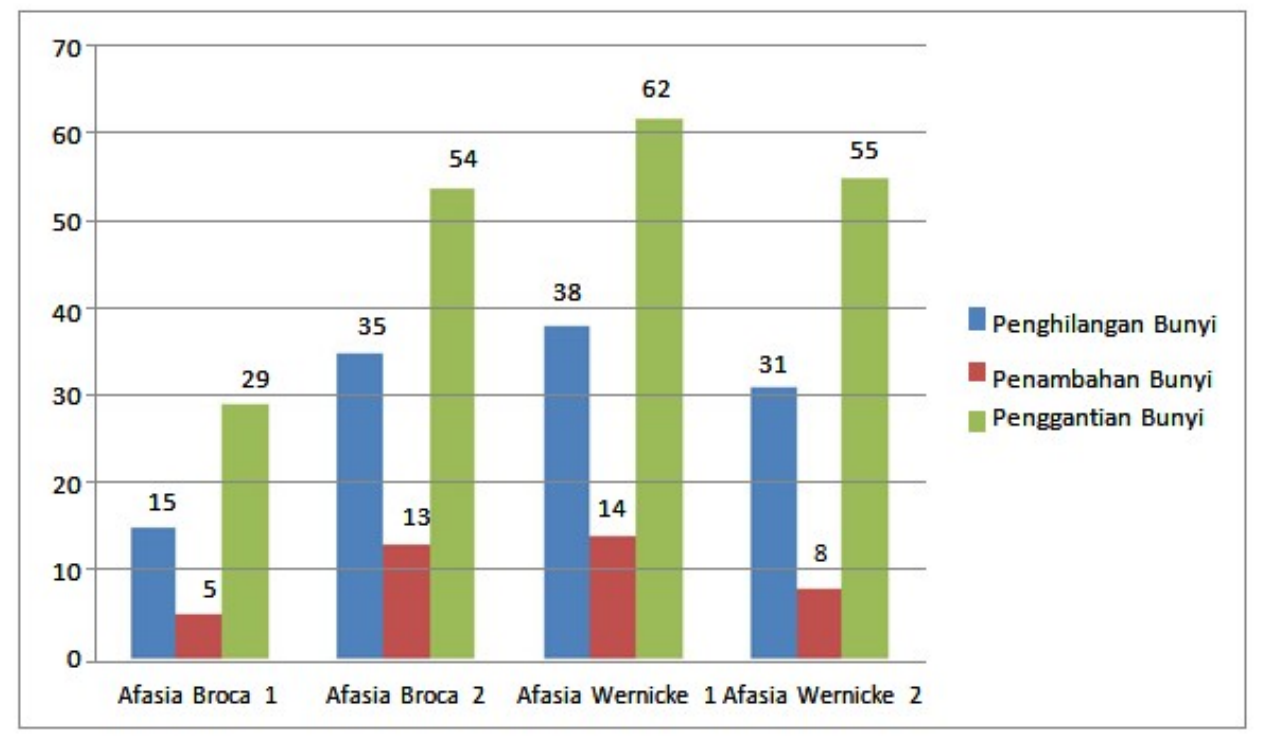

Bentuk kesalahan pengucapan yang dilakukan oleh penderita afasia Broca 1 sebanyak 49 kata. Kesalahan itu terdiri dari 15 kasus penghilangan bunyi, 5 kasus penambahan bunyi, dan 29 kasus penggantian bunyi. Kesalahan pengucapan yang mengalami penghilangan bunyi yaitu terjadi pada bunyi bilabial [w] sebanyak 1 kasus, apikodental [d] sebanyak 1 kasus, apikoalveolar [1] 3 kasus \& [n] 1 kasus, mediopalatal [c] 1 kasus, dorsovelar [g] \& [y] 1 kasus, dan pada bunyi faringal [h] 6 kasus. Kesalahan pengucapan yang mengalami penambahan bunyi hanya terjadi pada bunyi bilabial [w] sebanyak 5 kasus. Kesalahan pengucapan yang mengalami penggantian bunyi yaitu terjadi pada bunyi bilabial [b] $\rightarrow$ [p] 3 kasus dan [b] $\rightarrow$ [w] 1 kasus. Labiodental [v] $\rightarrow$ [p] \& [f] $\rightarrow[\mathrm{p}]$ masing- masing sebanyak 7 kasus. Apikodental $[\mathrm{t}] \rightarrow[\mathrm{w}] \&[\mathrm{f}] \rightarrow[\mathrm{w}]$ masingmasing sebanyak 1 kasus. Mediopalatal $[\mathrm{j}] \rightarrow[\mathrm{k}]$ sebanyak 1 kasus. Dorsovelar $[\mathrm{k}] \rightarrow[\mathrm{b}]$ $\&[\mathrm{k}] \rightarrow[\mathrm{p}]$ masing- masing sebanyak 1 kasus dan $[\mathrm{k}] \rightarrow[?]$ sebanyak 6 kasus.

Bentuk kesalahan pengucapan yang dilakukan oleh penderita afasia Broca 2 sebanyak 102 kata. Kesalahan itu terdiri dari 35 kasus penghilangan bunyi, 13 kasus penambahan bunyi, dan 54 kasus penggantian bunyi. Kesalahan pengucapan yang mengalami penghilangan bunyi yaitu terjadi pada bunyi bilabial [b] 1 kasus, [m] 5 kasus, [w] 2 kasus, labiodental [f] 1 kasus, apikoalveolar [t] 2 kasus, [r] 3 kasus dan [1] 8 kasus, mediopalatal [c], [j] \& [y] masing- masing 1 kasus, dorsovelar [g] \& [k] masing- masing 1 kasus \& [y] 3 kasus, faringal [h] sebanyak 5 kasus. Kesalahan pengucapan yang mengalami penambahan bunyi terjadi pada bunyi bilabial [p] 1 kasus \& [w] 9 kasus, bunyi dorsovelar [k] 2 kasus, dan bunyi faringal [h] 1 kasus. Kesalahan pengucapan yang mengalami penggantia $\mathrm{n}$ bunyi yaitu terjadi pada bunyi bilabial [b] $\rightarrow[\mathrm{p}] 3$ kasus, [b] $\rightarrow[\mathrm{t}]$ 1 kasus \& [m] $\rightarrow[\mathrm{w}] 2$ kasus. Labiodental [v] $\rightarrow[\mathrm{p}] 5$ kasus, [f] $\rightarrow[\mathrm{b}] 1$ kasus dan [f] $\rightarrow$ [p] sebanyak 5 kasus. Apikodental [d] $\rightarrow$ [t] sebanyak 1 kasus. Apikoalveolar [1] $\rightarrow[\mathrm{w}] 15$ kasus, $[1] \rightarrow[\mathrm{y}] \&[1] \rightarrow[\mathrm{y}]$ masing- masing 1 kasus, $[\mathrm{n}] \rightarrow[\mathrm{p}] \&[\mathrm{n}] \rightarrow[\mathrm{w}]$ masingmasing 2 kasus dan $[\mathrm{n}] \rightarrow[\mathrm{m}] 1$ kasus, $[\mathrm{t}] \rightarrow[\mathrm{k}] 1$ kasus, $[\mathrm{r}] \rightarrow[\mathrm{w}] \&[\mathrm{r}] \rightarrow[\mathrm{d}]$ masingmasing 1 kasus. Mediopalatal $[\mathrm{c}] \rightarrow[\mathrm{w}] \&[\mathrm{j}] \rightarrow[\mathrm{k}]$ masing- masing sebanyak 1 kasus. 
Dorsovelar [g] $\rightarrow[\mathrm{w}] 2$ kasus, $[\mathrm{g}] \rightarrow[\mathrm{h}] 1$ kasus, $[\mathrm{g}] \rightarrow[\mathrm{t}] 1$ kasus, $[\mathrm{k}] \rightarrow[\mathrm{s}] 1$ kasus \& $[\mathrm{k}] \rightarrow[?] 5$ kasus, dan [y] $\rightarrow[\mathrm{w}]$ sebanyak 1 kasus.

Bentuk kesalahan pengucapan yang dilakukan oleh penderita afasia Wernicke 1 sebanyak 114 kata. Kesalahan itu terdiri dari 38 kasus penghilangan bunyi, 14 kasus penambahan bunyi, dan 62 kasus penggantian bunyi. Kesalahan pengucapan yang mengalami penghilangan bunyi yaitu terjadi pada bunyi bilabial [b] 2 kasus, [p] 2 kasus, [m] 3 kasus dan [w] 1 kasus, labiodental [f] 1 kasus, apikodental [d] 1 kasus, apikoalveolar [t] 1 kasus, [n] 3 kasus, [r] \& [1] masing- masing 5 kasus, lamino alveolar [s] 1 kasus, mediopalatal [j] 1 kasus, dorsovelar [g] 1 kasus, [k] 6 kasus \& [y] 2 kasus, faringal [h] sebanyak 3 kasus. Kesalahan pengucapan yang mengalami penambahan bunyi terjadi pada bunyi bilabial [w] 10 kasus, bunyi apikoalveolar [t] \% [1] masing- masing 1 kasus, dorsovelar [k] 1 kasus, dan bunyi faringal [h] 1 kasus.

Kesalahan pengucapan yang mengalami penggantian bunyi yaitu terjadi pada bunyi bilabial [b] $\rightarrow[\mathrm{w}] 2$ kasus, [m] $\rightarrow[\mathrm{p}] 1$ kasus $\&[\mathrm{~m}] \rightarrow[\mathrm{w}] 2$ kasus. Labiodental [v] $\rightarrow[\mathrm{p}]$ 4 kasus dan [f] $\rightarrow[\mathrm{p}]$ sebanyak 2 kasus. Apikodental [d] $\rightarrow[\mathrm{w}]$ sebanyak 2 kasus $\&[\mathrm{~d}] \rightarrow$ [n] sebanyak 1. Apikoalveolar [1] $\rightarrow$ [w] 12 kasus \& [1] $\rightarrow$ [y] 3 kasus, [n] $\rightarrow[\mathrm{p}] \&[\mathrm{n}] \rightarrow$ [w] masing- masing 2 kasus, [r] $\rightarrow$ [w] 2 kasus. Laminoalveolar [s] $\rightarrow[\mathrm{w}] 2$ kasus, [s] $\rightarrow$ $[\mathrm{p}] \&[\mathrm{~s}] \rightarrow[\mathrm{m}]$ masing- masing 1 kasus. Mediopalatal [c] $\rightarrow[\mathrm{w}] 2$ kasus \& [j] $\rightarrow[\mathrm{k}]$ sebanyak 1 kasus. Dorsovelar $[\mathrm{g}] \rightarrow[\mathrm{w}] 2$ kasus \& [g] $\rightarrow[\mathrm{k}] 1$ kasus, $[\mathrm{k}] \rightarrow[\mathrm{w}] 3$ kasus \& $[\mathrm{k}] \rightarrow[\mathrm{p}] 1$ kasus, [k] $\rightarrow$ [1] 1 kasus, [k] $\rightarrow$ [?] 6 kasus, dan [y] $\rightarrow[\mathrm{w}]$ sebanyak 1 kasus.

Selanjutnya, bentuk kesalahan pengucapan yang dilakukan oleh penderita afasia Wernicke 2 sebanyak 94 kata. Kesalahan itu terdiri dari 31 kasus penghilangan bunyi, 8 kasus penambahan bunyi, dan 55 kasus penggantian bunyi. Kesalahan pengucapan yang mengalami penghilangan bunyi yaitu terjadi pada bunyi bilabial [b] 1 kasus, [p] 3 kasus, [m] 2 kasus dan [w] 3 kasus, labiodental [v] 1 kasus, apikoalveolar [t] 1 kasus, [n] 1 kasus, [r] 8 kasus \& [1] 4 kasus, lamino alveolar [s] 2 kasus, mediopalatal [c] 2 kasus, dorsovelar [g] 1 kasus dan [k] 2 kasus. Kesalahan pengucapan yang mengalami penambahan bunyi terjadi pada bunyi bilabial [w] 2 kasus \& [m] 1 kasus, bunyi faringal [h] 5 kasus.

Kesalahan pengucapan yang mengalami penggantian bunyi yaitu terjadi pada bunyi bilabial [b] $\rightarrow$ [w] 1 kasus, [b] $\rightarrow$ [p] 2 kasus, [p] $\rightarrow$ [w] 1 kasus, [m] $\rightarrow$ [w] 3 kasus \& $[\mathrm{m}] \rightarrow$ [1] 1 kasus. Labiodental [v] $\rightarrow$ [p] 2 kasus dan [f] $\rightarrow$ [p] sebanyak 3 kasus. Apikodental $[\mathrm{d}] \rightarrow[\mathrm{t}]$ sebanyak 1 kasus. Apikoalveolar $[\mathrm{t}] \rightarrow[\mathrm{w}] 2$ kasus $\&[1] \rightarrow[\mathrm{w}] 7$ kasus, [1] $\rightarrow$ [y] 2 kasus, [r] $\rightarrow$ [w] 5 kasus, [r] $\rightarrow$ [1] 3 kasus, [r] $\rightarrow[\mathrm{y}] 3$ kasus, $[\mathrm{r}] \rightarrow[\mathrm{h}]$ 6 kasus. Mediopalatal [c] $\rightarrow$ [t] 2 kasus \& [c] $\rightarrow$ [1] sebanyak 1 kasus. Dorsovelar [k] $\rightarrow$ [?] 6 kasus, [y] $\rightarrow[\mathrm{w}]$ sebanyak 1 kasus. Faringal [h] $\rightarrow$ [?] sebanyak 1 kasus.

\section{KESIMPULAN}

Pada penelitian ini penulis melakukan penelitian secara optimal, namun hasil penelitan ini masih kurang sempurna. Hal ini disebabkan oleh beberapa keterbatasan, antara lain: Instrumen penelitian ini adalah peneliti sendiri berupa dua pertanyaan pengarahyang bisa memancing wicara responden. Selain itu digunakan juga tes TADIR dan tabel pemeriksaan kemampuan wicara. Tes TADIR berfungsi untuk mengetahui tingkat keparahan afasia dan untuk mengetahui tingkat kesalahan berbahasa terutama pada pengucapan bunyi konsonan. Tabel pemeriksaan kemampuan wicara untuk mengetahui gangguan berbahasa pada penderita afasia Broca dan afasia Wernicke, terutama pada kesalahan gangguan fonologi, sehingga pada penelitian ini mendapatkan data yang lebih beragam. Namun, pada penelitian ini tidak semua daftar kata yang diucapkan oleh setiap penderita. Hal ini disebabkan oleh keadaan fisik penderita dan waktu penelitian yang terbatas. 
Informan yang baik dalam penelitian ini adalah seimbang antara laki- laki danperempuan yang berumur 40 tahun - 65 tahun. Namun, pada saat penelitian, informan yang dibutuhkan tidak sesuai keinginan peneliti karena keterbatasan informan yang menderita afasia Broca maupun Wernicke dapat terjadi pada setiap manusia tanpa melihat umur dan jenis kelamin. Oleh sebab itu, peneliti hanya dapat meneliti informan yang menderita afasia Broca dan afasia Wernicke yang ada di RSCM tanpa menentukan keseimbangan jenis kelamin informan. Peralatan yang digunakan untuk merekam suara penderita adalah tape recorderdan pengambilan gambar informan oleh kamera digital. Namun, kedua peralatan yang digunakan dalam penelitian ini masih banyak kekurangan yang peneliti dapatkan. Kendala yang dihadapi misalnya, suara informan yang direkam kurang jelas, adanya suara-suara lain yang terekam. Tidak semua penderita dapat diambil gambarnya, misalnya penderita afasia Wernicke 2 tidak mau diambil gambarnya. Berdasarkan analisis data yang diperoleh dari hasil penelitian, maka kesimpulan yang dapat ditarik adalah persamaan dan perbedaan kesalahan bunyi konsonan afasia Broca dan afasia Wernicke. Pengucapan kesalahan tunggal baik itu penghilangan, penambahan dan penggantian bunyinya. Hal ini tampak pada uraian berikut:

Bentuk-bentuk persamaan dari kesalahan bunyi konsonan dari afasia Broca dan afasia Wernicke yaitu: pada bunyi bilabial meliputi $[\mathrm{b}] \rightarrow[\mathrm{p}],[\mathrm{b}] \rightarrow[\mathrm{w}],[\mathrm{b}] \rightarrow[-],[\mathrm{m}] \rightarrow$ $[\mathrm{w}],[\mathrm{m}] \rightarrow[-],[\mathrm{w}] \rightarrow[+],[\mathrm{w}] \rightarrow[-]$. Pada bunyi labiodental meliputi [v] $\rightarrow[\mathrm{p}],[\mathrm{f}] \rightarrow[\mathrm{p}]$, $[\mathrm{f}] \rightarrow[-]$. Pada bunyi apikoalveolar meliputi [d] $\rightarrow[\mathrm{t}],[\mathrm{d}] \rightarrow[-],[\mathrm{t}] \rightarrow[\mathrm{w}],[\mathrm{n}] \rightarrow[\mathrm{p}],[\mathrm{n}]$ $\rightarrow[\mathrm{w}],[\mathrm{n}] \rightarrow[-],[\mathrm{r}] \rightarrow[\mathrm{w}],[\mathrm{r}] \rightarrow[-],[\mathrm{l}] \rightarrow[\mathrm{w}],[\mathrm{l}] \rightarrow[\mathrm{y}],[\mathrm{l}] \rightarrow[+]$. Pada bunyi med iopalatal meliputi $[\mathrm{c}] \rightarrow[\mathrm{w}],[\mathrm{j}] \rightarrow[\mathrm{k}],[\mathrm{j}] \rightarrow[-]$. Pada bunyi dorsovelar meliputi $[\mathrm{g}] \rightarrow$ $[\mathrm{w}],[\mathrm{g}] \rightarrow[-],[\mathrm{k}] \rightarrow[\mathrm{p}],[\mathrm{k}] \rightarrow[+],[\mathrm{k}] \rightarrow[-],[\mathrm{y}] \rightarrow[\mathrm{w}],[\mathrm{y}] \rightarrow[-]$. Pada bunyi faringal meliputi $[\mathrm{h}] \rightarrow[+],[\mathrm{h}] \rightarrow[-]$.

Kesalahan bunyi-bunyi konsonan yang hanya ada di afasia Broca yaitu: pada bunyi bilabial meliputi $[\mathrm{b}] \rightarrow[\mathrm{t}],[\mathrm{p}] \rightarrow[+]$. Pada bunyi labiodental meliputi $[\mathrm{f}] \rightarrow[\mathrm{b}],[\mathrm{t}] \rightarrow[\mathrm{k}]$. Pada bunyi apikoalveolar meliputi $[\mathrm{n}] \rightarrow[\mathrm{m}],[\mathrm{r}] \rightarrow[\mathrm{d}],[\mathrm{l}] \rightarrow[\mathrm{y}]$. Pada bunyi mediopalatal meliputi [y] $\rightarrow[-]$. Pada bunyi dorsovelar meliputi $[\mathrm{g}] \rightarrow[\mathrm{t}],[\mathrm{g}] \rightarrow[\mathrm{h}],[\mathrm{k}]$ $\rightarrow[\mathrm{b}],[\mathrm{k}] \rightarrow[\mathrm{s}],[\mathrm{k}] \rightarrow[$ ?].(3) Kesalahan bunyi-bunyi konsonan yang hanya ada di afasia Wernicke yaitu: pada bunyi bilabial meliputi $[\mathrm{p}] \rightarrow[\mathrm{w}],[\mathrm{p}] \rightarrow[-],[\mathrm{m}] \rightarrow[\mathrm{p}]$. Pada bunyi labiodental meliputi $[\mathrm{v}] \rightarrow[-]$. Pada bunyi apikoalveolar meliputi: $[\mathrm{d}] \rightarrow[\mathrm{w}],[\mathrm{d}] \rightarrow[\mathrm{n}],[\mathrm{t}]$ $\rightarrow[+],[\mathrm{t}] \rightarrow[-],[\mathrm{r}] \rightarrow[1],[\mathrm{g}] \rightarrow[\mathrm{k}],[\mathrm{r}] \rightarrow[\mathrm{y}],[\mathrm{k}] \rightarrow[\mathrm{w}],[\mathrm{r}] \rightarrow[\mathrm{h}],[\mathrm{k}] \rightarrow[1],[\mathrm{l}] \rightarrow[+]$. Pada bunyi laminoalveolar meliputi $[\mathrm{s}] \rightarrow[\mathrm{p}],[\mathrm{s}] \rightarrow[\mathrm{m}],[\mathrm{s}] \rightarrow[\mathrm{w}],[\mathrm{s}] \rightarrow[-]$. Pada bunyi mediopalatal meliputi [c] $\rightarrow[1],[\mathrm{c}] \rightarrow[\mathrm{t}],[\mathrm{c}] \rightarrow[-],[\mathrm{j}] \rightarrow$ [c]. Pada bunyi dorsovelar meliputi $[\mathrm{g}] \rightarrow[\mathrm{k}],[\mathrm{k}] \rightarrow[\mathrm{w}],[\mathrm{k}] \rightarrow[\mathrm{l}]$. Pada bunyifaringal meliputi $[\mathrm{h}] \rightarrow[?]$.

\section{DAFTAR RUJUKAN}

Ahlsén, Elisabeth. 2006. Introduction to Neurolinguistics. Amsterdam: John Benjamins Publishing Company.

Ahmad, HP. 2007. Pengantar Neurolinguistik. Jakarta: Universitas Negeri Jakarta. 2007. Materi Ajar Fonologi Seri Fonetik. Jakarta: Universitas Negeri Jakarta.

Alwi, Hasan dkk. 2000. Tata Bahasa Baku Bahasa Indonesia. Jakarta: Balai Pustaka

Chaer, Abdul. 2009. Fonologi Bahasa Indonesia. Jakarta: Rineka Cipta. 
Arkhais, Vol. 06 No. 2 Juli - Desember 2015

. 1994. Linguistik Umum. Jakarta: Rineka Cipta.

.2003. Psikolinguistik Kajian Teoritik. Jakarta: Rineka Cipta.

Dardjowidjojo, Soenjono. 1994. Linguistik Neurologi. Jakarta:

Lembaga Bahasa Unika Atmajaya.

. 1991. PELLBA 4. (Pertemuan Linguistik Lembaga Bahasa AtmajayaKeempat). Yogyakarta: Kanisius.

2003. Psikolinguistik: Pengantar Pemahaman Bahasa Indonesia. Jakarta: Yayasan Obor Manusia.

Dharmapewira, Reni. 1993. Afasia Deskripsi Pemeriksaan Penanganan. Jakarta: FKUI.

Edwards, Susan. 2005. Fluent Aphasia. Cambridge: Cambridge University Press.

Kridalaksana, Harimurti. 1982. Kamus Linguistik. Jakarta: Gramedia.

Kusumoputro, Sidiarto. 1992. Afasia: gangguan Berbahasa. Jakarta: Penerbit FKUI.

Mahsun, M.S. 2005. Metode Penelitian Bahasa (Tahapan, Strategi, Metode dan Tekniknya): Jakarta. PT. Raja Grafindo Persada.

Markam, Soemarmo. 1991. Hubungan Fungsi Otak dan Kemampuan Berbahasa Pada OrangDewasa (PELLBA 4). Yogyakarta: Kanisius

Marsono. 1986. Fonetik. Yogyakarta: UGM Press.

Muslich, Mansur. 2011. Fonologi Bahasa Indoensia. Jakarta: Bumi Aksara.

Schoenberg, Mike R. 2011. The Little Black Book of Neuropsychology. London: Springer New York Dordrecht Heidelberg London.

Setyono, Bambang. 2000. Terapi Wicara untuk Praktisi Pendidikan dan Kesehatan. Jakarta: Penerbit Buku Kedokteran EGC.

Sugiyono. 2011. Metode Penelitian Kualitatif, Kuantitatif dan $R \& D$. Bandung: Alfabeta.

Verhaar, J.M.W. 1996. Asas-Asas Linguistik Umum. Yogyakarta: Gadjah Mada University Press. 